\title{
The Effect of Additives on the Combustion Temperature of Cigarettes*
}

\author{
by Frank Miller**, Walter J. Freeman** and R. L. Stedman \\ Houdry Laboratories, Air Products and Chemicals, Inc., Marcus Hook, Pennsylvania, USA, \\ and Eastern Utilization Research and Development Division, U.S. Department of Agriculture, \\ Philadelphia, Pennsylvania, USA
}

INTRODUCTION

Alteration of the burn temperature of cigarettes is one of several concepts suggested as a means of reducing the level of benzo(a)pyrene (BAP) and other polynuclear hydrocarbons in smoke (1). Many studies have been concerned with the effects of temperature on the pattern of pyrolytic generation of BAP, phenol and other smoke constituents from a variety of precursors, and the major findings have been reviewed recently (1). In at least one instance (2), parallel biological tests have shown that pyrolytic temperature is directly related to the tumorigenic properties of the pyrolysates in animals. In general, however, extrapolation of pyrolytic data to the formation of smoke components during burning of a cigarette is tenuous. Profound qualitative (3) and quantitative differences (4) are noted on comparing pyrolysates and smoke condensates. To resolve the validity of this concept of combustion temperature alteration, it is necessary to find a means of achieving gradient temperature change in cigarettes during smoking. The present report describes a basic study of the effects of a wide variety of additives on combustion temperature.

METHODS

\section{Cigarettes and Smoking Conditions}

Commercial, $85 \mathrm{~mm}$ nonfilter cigarettes made in the United States were used in the study. All cigarettes were smoked in a constant volume smoking machine using the following conditions: puff volume, $35 \mathrm{ml}$; puff duration, $2 \mathrm{sec}$; and puff frequency, 1 per min. For controls, temperatures were obtained on one brand of cigarettes. For cigarettes containing additives, the tobacco cylinders were removed from the same brand of cigarettes, the tobacco mixed with the additive and the tobacco-additive mixture hand-rolled by machine into cigarettes as indicated below.

Additives

Several methods were used in making mixtures of tobacco and additives. Most frequently, the additive was ground, screened through a 200 mesh sieve and mixed intimately with the tobacco in a small, flexible bag. In a second method, the additive was dissolved in a solvent, the solution was sprayed on the tobacco and the solvent was removed by drying the mixture in an oven at $105^{\circ} \mathrm{C}$. $A$ third procedure involved spraying a precursor of the desired additive on the tobacco and precipitating or hydrolyzing the precursor to form the desired product in situ. For example, ferric

* Received for publication: 7th August, 1968.

4* Present address: Department of Chemisțy, University of Delaware, Newark, Delaware, 19711. 
oxide was obtained by spraying a given weight of tobacco with an equal weight of a finely divided aqueous suspension of ferric acetate, which was prepared by refluxing a $15: 1(\mathrm{w} / \mathrm{w})$ ratio of glacial acetic acid and iron powder; some ferrous iron was also present in the product as indicated by a positive o-phenanthroline test. The impregnated tobacco was then dried at $105^{\circ} \mathrm{C}$ in an oven and sprayed with steam to effect hydrolysis. Mixtures of tobacco and stannic oxide were similarly obtained by impregnation with alkalinized sodium stannate solution and subsequent release of the oxide by spraying with acetic acid after removal of solvent. All test and control cigarettes were equilibrated over saturated $\mathrm{NaBr}$ solution before smoking.

Glasses were prepared by fusing lead oxide and boron oxide in porcelain or fire clay crucibles using an oxygen-natural gas blast lamp. The melt was poured on a sheet of stainless steel plate or asbestos and, after cooling, the glass was ground in a ball mill.

In many cases, cigarettes would extinguish after lighting due to the additive. A small amount (usually $<_{1} \%$ ) of ferric oxide was then added to the cigarettes to maintain the burn. This level of the oxide did not influence the combustion temperature.

Moisture

Moisture determinations were performed by a modification of the Karl Fischer Method (5) and with the Ohaus Moisture Balance, both of which gave essentially comparable values.

Temperature Measurements

All measurements were made using a $\mathrm{Pt} / \mathrm{Pt}-13 \% \mathrm{Rh}$ thermocouple of either 0.001 or 0.002 in. diameter (6). In preliminary work, thermocouples of variable diameter and variable composition were also employed, including a DuPont* 900306 (0.012 in. diameter). For combustion temperature measurements, the thermocouple was inserted perpendicular to the longitudinal axis of the cigarette at a point $15 \mathrm{~mm}$ from the front end. In this position, the thermocouple varied in its location within the coal during the puffing of successive replicate cigarettes. To compensate for this, a sufficient number of replicates was run to yield an average value during a puff cycle which could be reproduced in a second set of replicates. Readings were disregarded when the thermocouple was visibly beyond the coal. Five to fifteen replicates usually sufficed, but more than 40 replicates were needed in some cases. The reported values are the mean \pm the range of all replicates for a given additive.

\section{RESULTS AND DISCUSSION}

Combustion temperatures of three commercial brands of cigarettes using a 0.001 in. diameter $\mathrm{Pt} / \mathrm{Pt}-13^{\circ} \% \mathrm{Rh}$ thermocouple were essentially similar $\left(871^{\circ} \pm 44^{\circ} \mathrm{C}, 866^{\circ} \pm 42^{\circ} \mathrm{C}\right.$ and $\left.847^{\circ} \pm 61^{\circ} \mathrm{C}\right)$ and within the acceptable range of values (6). Similar results were obtained with small (0.001 in. and $0.002 \mathrm{in}$.) diameter thermocouples of different composition (chromel/constantan, $\mathrm{Fe} /$ constantan and $\mathrm{Pt}$ coated with Tempilag, m. p. $1361^{\circ} \mathrm{C}$ ). A 0.012 in. diameter thermocouple gave temperatures about $150^{\circ} \mathrm{C}$ lower than the above. The temperatures recorded by the smaller diameter thermocouples were confirmed by the fusion of various salts placed in melting point tubes and inserted into the cigarettes. Sodium metavanadate (m. p. $630^{\circ} \mathrm{C}$ ), sodium iodide (m. p. $651^{\circ} \mathrm{C}$ ) and sodium chloride (m. p. $804^{\circ} \mathrm{C}$ ) fused, but barium chloride dihydrate (m. p. $925^{\circ} \mathrm{C}$ ) did not. Some slight sintering occurred with barium bromide dihydrate (m.p. $880^{\circ} \mathrm{C}$ ) and sodium sulfate (m.p. $884^{\circ} \mathrm{C}$ ). The addition of chemical agents to cigarettes produced a variety of changes in the burning characteristics, including a significant increase in the range of combustion temperature values obtained in replicates. Much of this variability was due to the well-known difficulties in getting uniformly packed cigarettes by hand-rolling. In all cases, attempts were made to distribute uniformly the additives within the tobacco in a cigarette but only partial success was evident in some instances. This variability made detection of small temperature differences impossible and rendered evaluation difficult without extensive statistical analysis. Since a choice was necessary between statistical analysis with a small number of additives or screening a large number of additives for large temperature alterations, the latter course was selected.

* Mention of a specific commercial product does not constitute endorsement by the Department over similar products not mentioned. 
A total of 97 additives were studied for effect on coal temperature, including members of the following groups:
1. Free radical initiators and inhibitors,
2. Salts of organic acids,
3. Inorganic salts and other compounds,
4. Lead-borate glasses,
5. Oxidizing agents,
6. Petroleum refining and oxidative catalysts,
7. Flame retardants and fire-proofing salts,
8. Miscellaneous compounds and mixtures.

Free radical initiators and inhibitors

The following agents were tested in concentrations of $3-25 \%$ : benzothiazyl disulfide, 2-mercaptobenzothiazole, tetraethylthiuram disulfide, benzyl disulfide, $\mathrm{N}$-bromosuccinimide, pyrogallol, azobenzene, dipentamethylenethiuram tetrasulfide, sulfur, chloranil, hydroquinone, diphenylamine, 2,2-diphenyl-1-picrylhydrazyl and 4,4'-dithiodimorpholine. None of the additives markedly altered the combustion temperature. Table 1 gives representative data for benzothiazyl disulfide and benzyl disulfide. Of all additives tested in the entire study, only these compounds gave some indication of a possible temperature elevation; however, with both additives, the temperature ranges of test and control cigarettes overlapped and the significance of the differences of the means is probably questionable.

\section{Salts of organic acids}

The following compounds were tested: $\mathrm{Ni}^{+2}, \mathrm{Ca}^{+2}, \mathrm{Mg}^{+2}, \mathrm{Fe}^{+3}, \mathrm{~Pb}^{+2}$ and $\mathrm{Sn}+2$ salts of oxalic acid; $\mathrm{Ni}^{+2}, \mathrm{Mg}^{+2}, \mathrm{Cu}^{+2}$ and $\mathrm{Co}^{+2}$ salts of formic acid; and strontium tartrate. In all cases, levels of $40-50 \%$ were necessary to obtain any noticeable effect on the coal temperature. Although large temperature alterations were not observed, nickel oxalate and stannous oxalate had a small depressive effect (Table 1).

The effect of some additives on the combustion temperature of cigareftes

\begin{tabular}{|c|c|c|c|}
\hline \multicolumn{2}{|c|}{ Additive } & \multicolumn{2}{|c|}{ Temperature range $\left({ }^{\circ} \mathrm{C}\right)$} \\
\hline Name & Concentration $(\% / \%)$ & Test cigarette & Control cigarette \\
\hline $\begin{array}{l}\text { Benzothiazyl disulfide } \\
\text { Benzyl disulfide } \\
\text { Azobenzene } \\
\text { Sulfur } \\
\text { Nickel oxalate } \\
\text { Stannous oxalate } \\
\text { Basic magnesium carbonate } \\
\mathrm{CaCO}_{3} \\
\mathrm{Na}_{2} \mathrm{CO}_{3} \\
\mathrm{NaCl} \\
\mathrm{Nal} \\
\mathrm{KBr} \\
\mathrm{AgBr} \\
\mathrm{Butox}^{*} 2^{* *} \\
\mathrm{~V}_{2} \mathrm{O}_{5} \\
\mathrm{KNO}_{3}\end{array}$ & $\begin{array}{r}7 \\
5 \\
25 \\
5 \\
50 \\
50 \\
20 \\
30 \\
40 \\
30 \\
40 \\
20 \\
40 \\
20 \\
35 \\
20 \\
20\end{array}$ & $\begin{array}{l}932 \pm 97 \\
918 \pm 69 \\
775 \pm 26 \\
899 \pm 79 \\
697 \pm 50 \\
739 \pm 37 \\
762 \pm 23^{*} \\
709 \pm 50^{*} \\
762 \pm 20 \\
737 \pm 17 \\
752 \pm 40^{*} \\
759 \pm 45 \\
749 \pm 34 \\
687 \pm 69 \\
682 \pm 42 \\
773 \pm 34 \\
767 \pm 31\end{array}$ & $\begin{array}{l}828 \pm 52 \\
853 \pm 75 \\
847 \pm 17 \\
837 \pm 26 \\
833 \pm 10 \\
853 \pm 47 \\
825 \pm 14 \\
826 \pm 25 \\
841 \pm 12 \\
841 \pm 12 \\
854 \pm 7 \\
823 \pm 10 \\
845 \pm 32 \\
843 \pm 17 \\
849 \pm 18 \\
835 \pm 6 \\
846 \pm 18\end{array}$ \\
\hline
\end{tabular}

* $\mathrm{F}_{02} \mathrm{O}_{2}(\leq 1 \%$ added to facilitate burning

** Commercial oxidative cotalyst 
The following additives were investigated: basic magnesium carbonate $\left[{ }_{4} \mathrm{MgCO}_{3} \cdot \mathrm{Mg}(\mathrm{OH})_{2} \cdot{ }_{4} \mathrm{H}_{2} \mathrm{O}\right]$, magnesite $\left[\mathrm{MgCO}_{3}\right], \mathrm{CaCO}_{3}$, dolomite $\left[\mathrm{CaCO}_{3} \cdot \mathrm{MgCO}_{3}\right], \mathrm{BaCO}_{3}$, basic zinc carbonate [ $5 \mathrm{ZnO} \cdot 2 \mathrm{CO}_{2}$ ] $\mathrm{Na}_{2} \mathrm{CO}_{3}, \mathrm{NaHCO}_{3}, \mathrm{~K}_{2} \mathrm{CO}_{3}, \mathrm{Mg}(\mathrm{OH})_{2}, \mathrm{Ca}(\mathrm{OH})_{2}, \mathrm{NaF}, \mathrm{NaCl}, \mathrm{NaI}, \mathrm{KCl}, \mathrm{KBr}$, $\mathrm{AgCl}, \mathrm{AgBr}, \mathrm{AgI}, \mathrm{B}_{2} \mathrm{O}_{3}, \mathrm{PbO}, \mathrm{\beta}-\mathrm{Al}_{2} \mathrm{O}_{3} \cdot{ }_{3} \mathrm{H}_{2} \mathrm{O}, \mathrm{Al}_{2}\left(\mathrm{SO}_{4}\right)_{3} \cdot 18 \mathrm{H}_{2} \mathrm{O}, \mathrm{ZnSO}_{4} \cdot{ }_{7} \mathrm{H}_{2} \mathrm{O}$ and $\mathrm{NH}_{4} \mathrm{H}_{8} \mathrm{PO}_{4}$. Seven of the salts produced variable degrees of depression (Table 1 ) at 20-40\% concentration but none gave a dramatic decrease. The claimed depression of alkali metal bicarbonates and $\beta$-alumina trihydrate appearing in the patent literature (7) could not be confirmed with certainty.

\section{Lead-borate glasses}

A large number of these additives were tested, including a few which contained small amounts of $\mathrm{ZnO}, \mathrm{CuO}$ and $\mathrm{SiO}_{2}$. The composition and temperature effects of some of the preparations are shown in Table 2. In almost all cases, the cigarettes had to be relighted to continue the smoking in spite of the presence of $\mathrm{Fe}_{2} \mathrm{O}_{3}$. Increasing the concentration of $\mathrm{Fe}_{2} \mathrm{O}_{3}$ from $0.17 \%$ to $0.68 \%$ had no effect on the burn temperature of cigarettes containing $81: 19-\mathrm{PbO}: \mathrm{B}_{2} \mathrm{O}_{3}(\mathrm{w} / \mathrm{w})$. In general, some depression was observed with glasses of different composition, but no large alteration was apparent.

TABLE 2

Effect of various glasses on the combustion temperature of cigarettes

\begin{tabular}{c|c|c|c|c|c|c}
\hline \multicolumn{3}{c}{ Composition $(\%)^{*}$} & & \multicolumn{2}{c}{ Temperature range $\left(^{\circ} \mathrm{C}\right)$} \\
\hline $\mathrm{PbO}$ & $\mathrm{B}_{2} \mathrm{O}_{3}$ & $\mathrm{ZnO}$ & $\mathrm{CuO}$ & $\mathrm{SiO}$ & Test cigarette* & Control cigarette \\
\hline 70 & 30 & 0 & 0 & 0 & $753 \pm 18$ & $839 \pm 11$ \\
70 & 20 & 10 & 0 & 0 & $731 \pm 63$ & $835 \pm \frac{6}{ \pm}$ \\
70 & 15 & 10 & 5 & 0 & $757 \pm 34$ & $840 \pm 19$ \\
81 & 19 & 0 & 0 & 0 & $756 \pm 49$ & $857 \pm 14$ \\
81 & 19 & 0 & 0 & 0 & $738 \pm 33$ & $836 \pm 26$ \\
84 & 16 & 0 & 0 & 0 & $899 \pm 15$ & $828 \pm 22$ \\
87 & 13 & 0 & 0 & 0 & $729 \pm 29$ & $845 \pm 15$ \\
90 & 10 & 0 & 0 & 0 & $714 \pm 26$ & $849 \pm 15$ \\
93 & 7 & 0 & 0 & 0 & $746 \pm 18$ & $835 \pm 16$ \\
96 & 4 & 0 & 0 & 0 & $755 \pm 23$ & $849 \pm 15$ \\
\hline
\end{tabular}

* Cigareftes with $70: 30$ and $81: 19-\mathrm{PbO}_{2}: \mathrm{B}_{2} \mathrm{O}_{3}$ also contained $0.68 \% \mathrm{Fe}_{2} \mathrm{O}_{3}$. Cigarettes with $81: 19-\mathrm{Pb}_{\mathrm{B}} \mathrm{B}_{2} \mathrm{O}_{3}$ had $\mathrm{O}_{2} 17 \% \mathrm{Fe}_{2} \mathrm{O}$. All cigarettes contained $30-40 \%$ additive.

Refining and oxidative catalysts

The following commercial catalysts were studied: Butox-2 (oxidative dehydrogenation catalyst, Houdry), ammonium exchanged and calcined molecular sieve (Davison), $\mathrm{HZ}-1$ (cracking catalyst, Houdry), reforming catalysts $\left(\mathrm{MoO}_{3}\right.$ or $\mathrm{Pt}$ on alumina gel, Houdry), hydrogenation catalysts (oxides of Mo and $\mathrm{Co}$ or $\mathrm{Pt}$ compound on alumina, Houdry), and oxidative catalysts (oxides of chromium or uranium on silica-alumina or pumice, Houdry). Only Butox-2 showed some depressive effect but large concentrations of catalyst were required (Table 1).

\section{Oxidizing agents}

The following compounds or mixtures were tested: $\mathrm{NaClO}_{3}, \mathrm{KIO}_{3}, \mathrm{~K}_{2} \mathrm{~S}_{2} \mathrm{O}_{8}, \mathrm{~V}_{2} \mathrm{O}_{5}, \mathrm{PbO}, \mathrm{Pb}_{3} \mathrm{O}_{4}$, $\mathrm{HgO}, \mathrm{KNO}_{2}, \mathrm{KNO}_{3}, \mathrm{MnO}_{2}, \mathrm{MnO}_{3}$ and a mixture of $\mathrm{KClO}_{3}+\mathrm{MnO}_{2}\left(95: 5^{\mathrm{w}} / \mathrm{w}\right)$. Of this group, only $\mathrm{V}_{2} \mathrm{O}_{5}$ and $\mathrm{KNO}_{3}$ showed some depressive activity (Table 1 ). The finding with $\mathrm{KNO}_{3}$ is of particular interest since the addition of $8 \% \mathrm{NaNO}_{3}$ has been shown to reduce BAP, phenol and nicotine levels in smoke and the tumorigenic activity of smoke in animals (8). However, the additive also produces higher levels of oxides of nitrogen (including $\mathrm{N}_{2} \mathrm{O}$ ), acrolein and related irritants in smoke (9). 
The following products were investigated: a water-insoluble polyphosphate [Phoscheck P/zo, Monsanto], tris(2,3-dichloropropyl)phosphate [Celluflex FR-2, Stauffer], tris( $\beta$-chlorethyl)phosphate [Celluflex CEF, Stauffer], tricresyl phosphate, tetrakis(hydromethyl)phosphonium chloride [Hooker], brominated triglycerides [Brominex 130, Swift], tetrabromophthalic anhydride [Firemaster $\mathrm{PHT}_{4}$, Michigan Chemical], a water-soluble powder based on ammonium sulfamate [DuPont $\mathrm{CM}$ ], a three component mixture of an ammonium salt, a nitrogen compound and a borate [X-12, DuPont], chromated zinc chloride [CZC, DuPont] and a mixture of $\mathrm{Na}_{2} \mathrm{~B}_{4} \mathrm{O}_{7} \cdot \mathrm{H}_{2} \mathrm{O}, \mathrm{H}_{3} \mathrm{BO}_{3}$ and $\mathrm{Na}_{3} \mathrm{PO}_{4}$ $(35: 50: 15 \mathrm{w} / \mathrm{w})$. At concentrations of $2-16 \%$, all of the above had no effect on burn temperature and, in most cases, higher levels of the additives extinguished the cigarettes immediately after lighting.

\section{Miscellaneous additives}

Polyvinyl chloride (5-10\%), silica gel ( $20 \%$ ), Molecular Sieve $5 \mathrm{~A}$ (Linde, 10-20\%), and a brazing powder containing $72 \% \mathrm{Ag}$ and $28 \% \mathrm{Cu}(5-15 \%)$ were tested as additives in the indicated concentration and found to have no dramatic effect on combustion temperature. Cigarettes containing polyvinyl chloride would not burn. Comparing the mean values for the combustion temperatures of the control cigarettes and the cigarettes containing the above molecular sieve, elevations of $18^{\circ} \mathrm{C}$ ( $10 \%$ concentration); $28^{\circ} \mathrm{C}$ ( $15 \%$ concentration) and $37^{\circ} \mathrm{C}(20 \%$ concentration) were obtained but the ranges of values of test and control cigarettes overlapped in all cases. Differential thermal analysis of this molecular sieve showed one sharp exotherm at $875^{\circ}-876^{\circ} \mathrm{C}$ and another at $>1000^{\circ} \mathrm{C}$. The former may be responsible for some slight elevation of combustion temperature in the test cigarettes.

Combustion Temperature in Oxygen

The temperature of the test cigarettes smoked in a $100 \%$ oxygen atmosphere was much more variable than in air. Values of $959 \pm 95$ (oxygen) and $849 \pm 30$ (air) were obtained. In one case, the thermocouple melted (m. p. Pt, $1773.5^{\circ} \mathrm{C}$ ).

Free Burn Temperatures

The free burn temperature of three brands of commercial cigarettes gave mean values of $820^{\circ}, 819^{\circ}$ and $819^{\circ}$, respectively, thus confirming earlier reports that only small differences $\left(₹ 75^{\circ} \mathrm{C}\right)$ are apparent between puff and free burn temperatures.

Moisture Levels

The tested additives have a wide range of hydroscopic properties. In many cases, hydrates were employed. Therefore, the moisture levels in the test cigarettes obtained on storage over $\mathrm{NaBr}$ saturated water gave a wide range of values. Adjustment of moisture of all cigarettes to the same value would have required an extensive study of humidifying conditions for each additive which would have reduced the number of additives tested. In the more than 320 combinations of additives and concentrations tested, a range of 5.0-18.3\% moisture was obtained. However, in most cases, the values for the impregnated cigarettes were in the approximate range of $7.0-11.0 \%$. The control cigarettes had a moisture content of $11.4 \%$. Since a depression of about $85^{\circ} \mathrm{C}$ in combustion temperature is observed on reducing the moisture of cigarettes from $13.1 \%$ to $4.7 \%$ (10), some of the slight temperature alteration observed above may have been due to this drying effect although this is not certain. On the other hand, many of the additives were hydrates and released water during smoking so that the water vapor content in the vicinity of the glow zone in relatively dry cigarettes may have been higher than that in cigarettes without additives but with higher moisture contents.

SUMMARY

A large number of cigarette additives was tested for the effect on the combustion temperature, including free radical initiators and inhibitors, salts of organic acids, inorganic salts and other inorganic compounds, lead-borate glasses, oxidizing agents, petroleum refining and oxidative 
catalysts, flame retardants, fire-proofing salts and other compounds and mixtures. Most of the additives showed no dramatic increase or decrease of temperature even at high concentrations but some indications of small alterations were obtained in a few cases.

\section{ZUSAMMENFASSUNG}

Bei einer großen Anzahl von Zusatzstoffen (additives), die bei der Herstellung von Cigaretten verwendet werden, wurde der Einfluß auf die Verbrennungstemperatur untersucht. Unter den geprüften Substanzen finden sich solche, die die Bildung von freien Radikalen begünstigen, und solche, die sie hemmen, Salze organischer Säuren, anorganische Salze und andere anorganische Verbindungen, Bleiborate, Oxydationsmittel, Katalysatoren mit oxidativer Wirkung und solche, die in der Erdölraffination eingesetzt werden, Entflammungshemmer, Salze, die zum Feuerschutz Verwendung finden, und andere Verbindungen und Gemische. Die meisten dieser Stoffe bewirkten keinen erheblichen Anstieg oder Abfall der Verbrennungstemperaturen, selbst wenn sie in hohen Konzentrationen verwendet wurden. Einige Anzeichen deuten jedoch auf geringfügige Änderungen in Einzelfällen hin.

RÉSUMÉ

L'étude a pour objet d'étudier l'influence d'un grand nombre d'additifs au tabac dont la plupart est énumérée ci-après sur la température de combustion de la cigarette: initiateurs et inhibiteurs de radicaux libres, sels d'acides organiques, sels inorganiques et autres composés inorganiques, borates de plomb, oxydants, catalyseurs d'oxydation et catalyseurs servant au raffinage du pétrole, retardateurs d'inflammation, sels réfractaires, et autres combinaisons et mélanges. Même avec de larges concentrations ajoutées, la température de combustion n'a été ni augmentée d'une manière considerable par la plus grande partie des composés examinés. Il y a eu, cependant, quelques cas indiquant de faibles altérations.

REFERENCES

1. Stedman, R. L.: Chem. Reviews 68 (1968) 153.

2. Wynder, E. L., Wright, G., and Lam, J.: Cancer 11 (1958) 1140.

3. Chortyk, O. T., Schlotzhauer, W. S., and Stedman, R. L.: Beitr. Tabakforsch. 3 (1966) 421.

4. Robb, E. W., Johnson, W. R., Westbrook, J. J., and Seligman, R. B.: Beitr. Tabakforsch. 3 (1966) 597.

5. Mitchell, J., Jr., and Smith, D. W.: Aquametry, p. 203, Interscience, New York, N. Y. 1948.

6. Touey, G. P., and Mumpower, R. C.: Tobacco Science 1 (1957) 33.

7. Stills, C. D., and Stedman, R. L.: Bull. d'Inform. CORESTA, No. 3 (1965) 6.

8. Hoffmann, D., and Wynder, E. L.: Cancer Research 27 (1967) 172.

9. Terrell, J. H., and Schmeltz, I.: Science 160 (1968) 1456.

10. Borowski, H., and Seehofer, F.: Beitr. Tabakforsch. 1 (1962) 329.

Acknowledgment

The study was carried out under contract with the Agricultural Research Service, U. S. Department of Agriculture, administered by the Eastern Utilization Research and Development Division, 600 East Mermaid Lane, Philadelphia, Pennsylvania, 19118, USA.

The authors' addresses:

Air Products and Chemicals, Inc., Houdry Laboratories, Marcus Hook, Pennsylvania, 19061, USA

Eastern Utilization Research and Development Division, Agricultural Research Service, United States

Department of Agriculture, Philadelphia, Pennsylvania, 19118, USA 